\title{
SAME-SEX MARRIAGE IN SOUTH AFRICA: THE ROAD AHEAD
}

\author{
JA Robinson and J Swanepoel \\ North-West University (Potchefstroom Campus)
}

[E]ven people with a heterosexual orientation are experiencing their gender identity - womanhood or manhood - as a problem and as an option, rather than as something they can take for granted ...

But if a mind that is geared towards pragmatic expediency seeks to destroy everything that is not immediately plausible or does not promise any direct benefit, then such a mind inadvertently removes the basis from a modern person's claim to freedom and self-fulfilment. In the long term, this leads to the formation of structures which are the very opposite of what we once regarded as the basis and condition of freedom. ${ }^{1}$

\section{Introduction}

The status of same-sex partnerships is currently a hotly debated issue in various jurisdictions and also in South Africa. Section 9 of the Bill of Rights in the Constitution of the Republic of South Africa $^{2}$ prohibits unfair discrimination by the State, inter alia, on grounds of gender, sex and sexual orientation. The question that arises is whether the legal definition of marriage, being a relationship between one man and one woman, constitutes discrimination, and if so, whether such discrimination is unfair. ${ }^{3}$

The legal position has become acute in South Africa. Legal uncertainty prevails with regard to the legal status of such couples. Various applications have been brought before branches of the High Court and the Constitutional Court for relief relating to particular personal and patrimonial consequences of marriage. ${ }^{4}$ In some cases the respective courts had to establish on

1 Trost 2002 Kirchliche Umschau 29. (Hereafter referred to as Braun I.) For the sake of convenience it will be accepted that the claim of homosexual couples is for marriage. That is however not necessarily the case. In a paper presented by Coester 2002 Eur J Fam L on the topic of same-sex relationships at the University College of London, 26 February 2002, reference is made to Tatchell, an English advocate for homosexual rights, who argues as follows: "We certainly do not believe that queers should copy a fundamentally flawed heterosexual institution ... The most serious campaigners for marriage are now conservative gays and religious fundamentalists ... Having enjoyed the greater life style choices and sexual freedom that go with being gay, we'd be crazy to don the straightjacket of wedlock." Glendon 1976 Virginia Law Review 684 quoted in Coester states that "[t]hose exercising the 'right to marry' may find that life on the other side of the door they have tried so hard to open is not much different from life on the outside. In passing through the door, they may encounter an unlooked-for intimacy with the State."

2 Constitution of the Republic of South Africa, 1996.

3 See Harksen v Lane 19981 SA 300 (CC); 1997 (11) BCLR 1489 par [54].

4 See Langemaat $v$ Minister of Safety and Security 19982 All SA 259 (T); National Coalition for Gay and Lesbian Equality v Minister of Home Affairs 19993 SA 173 (C); Satchwell v The Minister of Justice and Constitutional Development Case Nr CCT 45/01; Du Toit v Minister of Welfare and 
an ad hoc basis whether a long term relationship indicative of a marriage-like relationship existed in order to bestow the particular relief requested by the applicant couple. The very fact that an ad hoc determination has to be made because, of course, there is no celebration of a valid marriage, creates an untenable situation for such couples.

The question posed above, forms the focal point of serious, and often insulting, legal debate. This contribution endeavours to give a brief overview of the various viewpoints, and thereafter to add to the debate.

\section{The debate}

Marriage in South African common law is defined as the legally recognised voluntary union for life in common of one man and one woman to the exclusion of all other while it lasts. ${ }^{5}$ This definition has been under severe attack from various sources and for various reasons. Sinclair and Heaton point out that a cursory glance at some of the major changes in Western societal attitudes and behaviour, several of which have been translated into reform of family law, reveals a growing number of different life-styles that calls for a more flexible approach to the definition of the so-called Christian marriage. ${ }^{6}$ It is indeed true that the common law definition reflects a Christian-Western concept of marriage. ${ }^{7}$

Marriage plays an important social role ${ }^{8}$ and the exclusion of homosexuals from the institution forces the constitutional issue. It would appear that arguments against maintaining the status

Population Development 2001 (12) BCLR 1225 (T); J v Director General: Department of Home Affairs 20035 SA 605 (D\&CLD). See also Pantazis 2002 SALJ 305.

5 Sinclair and Heaton Law of Marriage 305. A decision often quoted by South African courts is Hyde $v$ Hyde and Woodmansee (1866) LR 1 P\&D 130 at 133 where it was held that: "Marriage as understood by Christendom, may ... be defined as the voluntary union for life of one man and one woman to the exclusion of all others." See further in this regard Seedat's Executors v The Master (Natal) 1917 AD 302 at 309. Of course, a major development in South African law is the Recognition of Customary Marriages Act 120 of 1998 which came into operation on 15 November 2000. This Act gives full legal recognition to customary marriages and it applies to all customary marriages regardless of when it was concluded. This Act certainly serves to prove that the South African legislature is prepared to remedy aspects of common law not apposite for South Africa.

6 Sinclair and Heaton Law of Marriage 305. Empirically speaking a great variety of forms of marriage or marriage-like structures can be discerned. The way in which marriage is conceptualised (eg as a monogamous or polygamous union) and how it has been regulated has varied greatly with time and culture (with the church and state claiming this authority at various stages). Cf Witte Religion and Law.

7 A definition does not only provide information on the phenomenon that is being defined. It also sheds light on the person making the definition, the social context in which he/she operates, and often about the dominant value system of a particular society. Seeing that Christianity had such a profound influence on the Western world, it is not at all strange that the common law definition reflects a Christian concept of marriage.

8 Culhane 1999 Cardozo L Rev 1180 quoted by MacDougall 2000-2001 Ottawa Law Review 235. At 242 MacDougall explains the symbolism of marriage. He conveys that it is the institution that accords to a 
quo focus on three interrelated aspects that underlie the upholding of the common law definition. These are tradition/definition/nature of things, religion/morality and sex/children.

\section{Tradition/Definition/Nature of things}

The argument in this regard attacks the traditional/definitional acceptance of marriage as the relationship between a male and a female. An example of the traditional approach was set out in sections 8 and 9 of the Judges' Remuneration and Conditions of Employment Act ${ }^{9}$ which provided

[S]ubject to the provisions ... the surviving spouse of a Judge who on or after the fixed date was or is discharged from active service, shall be paid with effect from the first day of the month immediately succeeding the month in which he dies an amount -

(a) in the case of a surviving spouse of a Judge who was so discharged ...

(b) in the case of a surviving spouse of a Judge who died ...'

In the case of Satchwell, ${ }^{10}$ Court followed the approach of the decision in National Coalition for Gay and Lesbian Equality $v$ Minister of Home Affairs ${ }^{11}$ and dealt as follows with the approach. It held that the word 'spouse' could not be read to include 'same-sex partner'.

The context in which 'spouse' is used in the impugned provisions does not suggest a wider meaning, nor do I know of one. ${ }^{12}$

union the profound social stamp of approval and acceptance as being of the highest value. In fact, those who choose to marry are often provided with deep, warm and broad support from society. Reference is also made to Eckols 1999 Mich J of Gender and L 354 who writes: "Often marriage is considered a foundational unit of civilized society, but is also an anchor for an individual's identity. One is married when in the office, at a business lunch ... Marriage is legal, religious, social vocational, and personal. ... The power of marriages comes not from what it is in the abstract, or how it is defined, or even what it symbolizes, but from how it is transubstantiated by society's focus on marital status as a key element in defining every person." Braun I (n 1) at 29 criticizes the German Gesetz zur Beendigung der Diskriminierung Gleichgeschlechtlicher Gemeinschaften of 2001 on this very ground. He explains that the Act has immense symbolical significance since the legislator now signals that the State sees homosexual and heterosexual behaviour as being of equal value.

$9 \quad$ Judges' Remuneration and Conditions of Employment Act 88 of 1989.

10 Supra n 4

11 National Coalition for Gay and Lesbian Equality v Minister of Home Affairs 20002 SA 1 (CC); 20001 BCLR 39 (CC).

12 Supra par [9]. In the Canadian case of $M v H$ [1999] 2 SCR 3, 171 DLR $\left(4^{\text {th }}\right) 577$ quoted in MacDougall 2000-2001 Ottawa Law Review 245, a similar approach is followed: "The definition of 'spouse' ... is an extension of marriage. To be a spouse is, in essence, to be as if married, whether or not one is actually married. Spousehood is a social and cultural institution, not merely an instrument of economic policy. The concept of 'spouse', while a social construct, has deep roots in our history ... it is 
The traditional approach is also reflected in the argument of Braun that the German Constitution does not mention anywhere that spouses must be of the opposite sex -

[d]ies aber nicht deshalb, weil es dem Verfassungsgeber darauf nicht ankam, sondern allein darum, weil ihm dies ... so selbstverständlich erschien, daß er sich etwas anderes gar nicht vorstellen konnte..$^{13}$ (Italics added)

The traditional approach has been severely criticized. In the first place mention is made of its rigidity.

[T] o say to homosexuals that their incapacity is relative - they can marry, but they must marry a person of the opposite sex - is not a good enough answer. ${ }^{14}$

Furthermore, the acceptance of the definitional/traditional approach fails to explore the underpinnings of the definition - as such it is inadequate in that it does not provide a broader principle through which to understand why marriage should be limited to a particular kind of human experience. ${ }^{15}$ Thirdly this approach is accused of being out of step with recent

rooted in Western history, in which the concept of "spouse" has always been referred to as a member of a cohabiting opposite-sex couple. ... That well-recognised definition does not discriminate on the basis of sexual orientation any more than the status of "child" or "adult" discriminates on the basis of age, or "male" or "female" discriminates on the basis of sex.

13 Braun 2002 Juristenzeitung 25 (hereafter Braun II). He continues as follows: "Die Ehegatten repräsentieren, wie bereits die Name andeutet, in ihrer Zweiheit die menschliche Gattung. Das setzt voraus, daß sie verschiedenen Geschlechts sind. Nur als Urform der Gattung und damit zugleich als Keimzelle der Gesellschaft ist die Ehe geschützt." In Bundesverfassungsgerichtentscheidung of 17 July 2002 with regard to the recognition of same-sex relationships, the German Constitutional Court explained it thus at par 79: "Jeder ehefähigen Person steht auch nach Einführung der eingetragenen Lebenspartnerschaft durch das LpartDisBG der Weg in die Ehe offen. Allerdings kann die Ehe nur mit einem Partner des jeweils anderen Geschlechts geschlossen werden, da ihr als Wesensmerkmal die Verschiedenengeschlechtlichkeit der Partner innewohnt und sich nur hierauf das Recht der Eheschließungsfreiheit bezieht." See also Strasser 1997 Legally Wed 10. He refers to Jones v Hallahan 501 SW 2d 588 (Ky 1973) where the Kentucky Supreme Court suggested that the state of Kentucky was not invidiously discriminating against two women by refusing to allow them to marry. Two women are "prevented from marrying, not by the statutes of Kentucky or the refusal of the County Court Clerk ... to issue them a license, but rather by their own incapability of entering into a marriage as that term is defined."

14 Sinclair and Heaton Law of Marriage $169 \mathrm{n}$ 460. A rather extreme argument is found in the decision of Southey J in Layland $v$ Ontario (Minister of Consumer and Commercial Relations) (1993), 14 OR (3d) 658, 104 DLR $\left(4^{\text {th }}\right) 214$ (Div Ct) quoted in MacDougall $241 \mathrm{n} 22$. The law does not prohibit marriage by homosexuals, provided it takes place between persons of the opposite sex. Some homosexuals do marry. The fact that many homosexuals do not choose to marry, because they do not want unions with persons of the opposite sex, is the result of their own preferences, not a requirement of law.

15 Allen, quoted in MacDougall 2000-2001 Ottawa Law Review 246 n 54 explains this argument thus: "The argument that, by definition, marriage can involve only a man and a woman because it has always included only opposite-sex couples, is tautological ... The fact that marriage has not included same-sex couples in the past does not explain why that cannot be so now anymore ...". 
developments. In this regard reference is made to the redefinition of "spouse" in recent case law and legislation and the acceptance of the idea of evolving social concepts. ${ }^{16}$

Another argument put forward is that heterosexual marriage provides social stability, the glue for which homosexual relationships lack. Reference is made to case law where respective courts conveyed that heterosexual relationships differ radically from homosexual ones in the sense that those in heterosexual relationships develop a "dynamic of dependence" that is not usual in homosexual relationships. ${ }^{17}$ This dynamic of dependence reduces autonomy and increases attachment in heterosexual relationships. Behind this argument, MacDougall argues, lays the idea that homosexual relationships are not so stable or committed as heterosexual relationships - the fruit of stigmatizing stereotypes. This approach is referred to as a mystical conception which does not conform to the reality of heterosexual married couples. ${ }^{18}$

A fourth aspect raised as critique against the definitional approach is that the contested nature of heterosexual marriage is rendering the approach increasingly inadequate - it has become unsatisfactory to say that same-sex relationships do not meet the traditional definition of marriage when the very definition is challenged. ${ }^{19}$

Lawyers, of course, have a special aptitude and predilection for definitions. This love for definitions and the penchant for an analytical approach are part and parcel of modern jurisprudence. It should be kept in mind that law operates with normative definitions; and that it does not simply describe factual situations. Legal consequences flow from whether a state of affairs/phenomenon is adjudged to be in accordance with the legal definition or not. Although definitions play an important role in the legal context, one should also pay attention to the broader intellectual context of our times. While South Africa as a developing country exhibits characteristics of pre-modernism, modernism and postmodernism, the late twentieth century and the early twenty first century can - intellectually speaking - be characterized as a period in which postmodernism is progressively gaining influence. It is an era that dislikes hierarchies, is sensitive to imbalances in power, doesn't regard things as fixed, that is averse to closure, that

16 Eg Langemaat (n 4); Satchwell (n 4); National Coalition for Gay and Lesbian Equality (n 4). See also De Vos 1996 SAJHR 274.

$17 M v H[1999] 2$ SCR 3, 171 DLR $\left(4^{\text {th }}\right) 577$.

18 MacDougall 2000-2001 Ottawa Law Review 247. He also refers to the dictum of Cory J in Egan $v$ Canada [1995] 2 SCR 513, 124 DLR $\left(4^{\text {th }}\right) 609$ that gay and lesbian couples do not have to have the perfect relationship in order to make a relation-based claim in the courts. Such relationship does not have to show perfect compliance with the traditional heterosexual ideal of what it means to be a couple to make a relationship-based claim in the courts. In fact, the relationship does not have to be textbook perfect as heterosexual relationships rarely are. 
attempts to expose vested interests, and - especially - that refuses to regard anything as natural (fixed by nature) or as a given. Postmodernists see the world and especially social relationships as a construct. Hence it has a predilection for play, creativity, the postponement of meaning and the deconstruction of hierarchies. In the well-known words of Hutchinson: "There is nothing there until we put there there." ${ }^{20}$ Applied to marriage this entails that marriage is not something fixed by nature, but is what people decide marriage is.

Formatted: Bullets and Numbering

\section{Religion/morality}

Arguments in opposition to religion ${ }^{21}$ qua basis for considering marriage only as a relationship between a man and a woman, are broadly expressed in phrases stating that religious ideology cannot be used to determine what people who are not of that religion can do or how they should lead their lives. ${ }^{22}$ From this perspective it is clear that permitting same-sex marriage would not impinge upon religious freedom. ${ }^{23}$

The argument against moral justification for a male-female relationship attacks the "natural" basis for the relationship and conveys that same-sex relationships (whether of the male-male or female-female kind) are not contrary to nature. The "morality criticism" to some extent is a mere extension of the religion argument in that the "laws of nature" to which marriage was supposed to conform, were the laws of nature as generally recognized in Christian countries. ${ }^{24}$

19 MacDougall 2000-2001 Ottawa Law Review 246. See also De Vos 1996 SAJHR 283 et seq.

20 Hutchinson 1985 New York University Law Review 853.

21 The definition of marriage still prevailing in South Africa is that of Hyde $v$ Hyde and Woodmansee (1866) LR 1 P\&D 130 which definitely links marriage to Christian values. The same sentiments are echoed by Joubert in Van der Vyver and Joubert Persone- en Familiereg 447. He conveys that the law of marriage in South Africa has been influenced particularly by the Christian faith. More specifically, marriage passed under the jurisdiction of the Church in the Middle Ages in Western Europe. It was elevated to a sacrament and once consummated, it was indissoluble by any human agency - "What God hath joined together let no man put asunder". See also Sinclair and Heaton Law of Marriage 388.

22 Strasser Legally Wed 12: "If one wishes to argue that the state should not recognize same-sex marriages because God does not recognize them, then one is presumably offering a fairly comprehensive claim about what nearly all traditions believe. However, some religious traditions accept and recognize same-sex unions."

23 From a South African perspective, the situation is not as simple, though. The test in Harksen $v$ Lane (n 3) must still be kept in mind. See also text accompanying n 57 infra.

24 Culhane 1999 Cardozo L Rev 1187 explains that once the Bible is acknowledged as an indirect source of morality, the question to be addressed is what independent moral reason remains for opposing samesex unions. "This crucial step is tellingly missing from most the religious objections to same-sex marriage." See, however, De Vos 1996 SAJHR 277. 
This aspect of critique is levelled at viewpoints such as those of Braun ${ }^{25}$ who strongly contends that it is important for children to grow up in a heterosexual marriage.

[w] as die Ehe von anderen Beziehungsformen unterscheidet. Daß sich die Ehe in der auf Individualisierung und Flexibilisierung angelegten modernen Gesellschaft behauptet hat, hängt weniger damit zusammen, daß sie die Aussicht bietet, mit Hilfe von Rechtszwang die Zweisamkeit auf Dauer stellen zu können. Der eigentliche Grund ist vielmehr der, daß das immer größer werdende Wagnis, eine Familie mit Kinderen zu gründen, nur in einer institutionell verfestigten Beziehung verantwortet werden kann. Diesen Grund gibt es bei gleichgeschlechtlichen Partnern nicht. Zwar kommen hier auch dauerhafte Partnerschaften vor. Diese erschöpfen sich jedoch in den Beziehungen der Partner selbst und sind dadurch von wesentlich anderer Natur. Die Ehe ist zugleich potentielle Elternschaft; eine gleichgeschlechtliche Partnerschaft ist dies nicht.

He furthermore conveys that human sexuality is domesticised in marriage and family in such way as to comply with societal demands. Phrases such as

"[b]iological and social realities that heterosexual couples have the unique quality to procreate, that most children are the product of these relationships, and that they are generally cared for and nurtured by those who live in that relationship. In this sense marriage is by nature heterosexual."

bear out on the argument of Braun. ${ }^{26}$

This argument is not accepted by protagonists of same-sex marriage. It is especially the "unique" and "natural place for raising children"-aspect that comes under attack. Children can be, and many are, raised outside heterosexual relationships. In fact, in many heterosexual relationships one of the couple often has very little to do with raising the children. Furthermore

25 Braun 2002 Juristenzeitung 25 (Braun II). See also Wardle Same-sex Marriage 381-390; MacDougall 2000-2001 Ottawa Law Review 248.

26 MacDougall 2000-2001 Ottawa Law Review 249. See also Baxter v Baxter [1948] AC 274 [1947] 2 All ER 886 (HL) where the court linked the aspect of children in marriage directly to Christianity: "Again, the insistence on the procreation of children as one of the principal ends, if not the principal end, of marriage requires examination. It is indisputable that the institution of marriage generally is not necessary for the procreation of children; nor does it appear to be the principal end of marriage as understood in Christendom. ... In any view of Christian marriage the essence of the matter, as it seems to me, is that children, if there be any, should be born into a family as that word is understood in Christendom generally ... But that is not the same thing as saying that a marriage is not consummated unless children are procreated or that children is the principal end of marriage." 
it is a fact that many heterosexual couples do not have children. ${ }^{27}$ It is furthermore rejected that same-sex marriages will of necessity cause harm to children. ${ }^{28}$

\section{Concluding remarks}

Heterosexual marriage is the oldest gender-equality institution in law. The requirement that marriage consists of both a man and a woman emphasises the equality and equal necessity of both sexes for society's most fundamental unit. It recognises the indispensable and equal contribution of both genders to this institution. ${ }^{29}$

Although telling points are made on both sides of the debate, it is suggested that none of the arguments advanced in the debate both pro and contra same-sex marriage are legally sufficient. The mere acceptance by legislators that marriage is heterosexual without further ado, fails to explain whether there are fundamental differences between hetero- and

27 MacDougall 2000-2001 Ottawa Law Review 250. In a South African context, reference should be made to Venter v Venter 19494 SA 123 (W) and Van Niekerk v Van Niekerk 19594 SA 659 (GW). In Venter at 128 the court held that it cannot be said that the procreation of children is so essential an element of marriage that, where it cannot come about, there is no marriage. A general rule that a marriage can be annulled if one of the parties were incapable of procreating at the time of the marriage may lead to the setting aside of many a marriage of old persons. Incapacity of itself does not justify declaring a marriage void. In Van Niekerk, on the other hand, it was held that the mere fact of sterility renders a marriage voidable, regardless of whether it was fraudulently concealed or not. This, however, only applies to those cases where the procreation of children was an express or implied object of the marriage.

28 The harm children would encounter by being exposed to a lesbian relationship was the reason why an application for alteration of access to children was rejected in Van Rooyen $v$ Van Rooyen 19942 SA 325 (WLD). The court concluded that any right thinking person would say that it is important that children stay away from "confusing signals" as to how the sexuality of the male and female should develop. Such signals are given by the fact that the children know that, contrary to what they should be taught as normal or what they should be guided to as to be correct (that is, a male and a female sharing a bed) two females are doing this as a matter of preference and of mutual emotional attachment. This is detrimental to the child because it is the wrong signal.

Van Rooyen has been emphatically rejected in South African law. In Ex parte Critchfield 19993 SA 132 (WLD) the court concluded that in a society such as ours which proscribes discrimination on the basis of sexual orientation, such encounters can be viewed in no more serious a light the than conventional adultery. In fact the court is of the opinion that it should not be particularly concerned with the sexual predilections of litigants when it comes to custody matters: "It encourages voyeurism in public life that demeans us all. It is an entirely different matter where such predictions pose an actual or potential threat to the welfare, psychological or physical, of young children."

In $V v V 19984$ SA 169 (C) it was found that the court in Van Rooyen had made a moral judgment about what was normal and correct with regard to sexuality and about homosexuality which it found to be abnormal per se. The court referred to the limitations allowed by the Constitution on fundamental rights and explained that there may well be situations where a court will override the equality clause in the best interests of the child. A discriminating order by a court against a lesbian mother for access rights to her children that is based solely on her sexual orientation will not easily pass constitutional muster.

29 Wardle Same-sex Marriage 392. 
homosexual relationships. Gender and $\operatorname{sex}^{30}$ do indeed play a predominant role in arguments pro- and contra same sex marriage and rightly so. It should, however, be kept in mind that marriage comprises also other aspects, very importantly love, apart from the sexual. ${ }^{31}$ By simply accepting without further motivation that marriage is heterosexual in nature, or by attacking the heterosexual nature on the basis of some empirical evidence, reflects a superficial view of the nature of marriage.

Equally true is that arguments supporting either side of the dispute which are based on religion or morality may infringe upon constitutionally entrenched rights of others not belonging to the particular religion. ${ }^{32}$ It is furthermore suggested that references to children growing up in a heterosexual family environment to substantiate particular arguments do not pertain to the nature of marriage but rather relate to issues surrounding the best interests of children.

Arguments favouring same-sex marriage, it is suggested, ignore the conceptual framework within which to understand the institution. These arguments embrace the myth about the lawmaker and the legal system that is based upon an erroneous impression of the origin, content and structure of law. It hides the fact that the central elements of a legal order cannot be invented by a law-maker, but must be rooted in a normative practice. ${ }^{33}$

The true nature of marriage, as will be discussed infra, is to be found in the fact that it creates a consortium omnis vitae, a social entity with its own unique character. It is argued that it is in this vital respect that homosexual relationships can not be equated with marriage.

30 Sex refers to the biological differences between men and women, while gender refers to the social roles associated with man- and womanhood. While sex belongs to the natural dimension, gender is regarded as a social construct. It will be noted that the Constitution does indeed in s 9 distinguish between the terms sex and gender. In literature on the topic of same-sex marriages the terms are sometimes used interchangeably.

31 An attempt in this regard is the so-called PVP-potential (penis-vagina-penetration). Some authors argue that the central criterion for recognition of legal marriage is not love, companionship or heterosexual identity, but in fact the potential to engage in PVP. Robertson 1998 Denver UL 1375 quoted in MacDougall 2000-2001 Ottawa Law Review 251.

32 S 15 of the Constitution guarantees everyone "the right to freedom of conscience, religion, thought, belief and opinion".

33 Par 3 infra. See also Wardle Same-sex Marriage 392 who argues as follows: "Advocates of same-sex marriage make the pluralistic flaw of believing that if they can get the label of marriage for their gay and lesbian relationships, they will magically acquire the socially and individually beneficial characteristics associated with marriage ... Abraham Lincoln once lampooned the flaw of this thinking with a homespun story: he asked how many legs a dog would have if you counted a tail as a leg. To the response 'five legs', Lincoln said, 'No, calling a tail a leg doesn't make it a leg'. ... It is not the marriage certificate, the label, or legal status that makes the heterosexual marital relationship uniquely beneficial to individuals and society, but it is the nature of the relationship itself that is so valuable, and that is why such unions are given preferred a legal status (and a label) of marriage." See also De Vos 1996 SAJHR 289. 


\section{Theoretical viewpoint - marriage as a social entity}

Since marriage creates particular obligations for the spouses involved, it may at first glance appear to have the same legal nature than "ordinary contracts". However, there are major differences between these two legal phenomena, which lead Joubert to conclude that marriage rather constitutes a juristic act sui generis. ${ }^{34}$ This conclusion is justified; it is submitted, in view of the fact that marriage creates more than reciprocal personal rights and obligations. It creates a "regstaat" that influences the status of the parties. The difference is borne out, inter alia, by the fact that contractual obligations may be sanctioned by orders for specific performance or for damages and even for interdicts. The position of spouses is regulated differently and a court will not, for instance, grant an order for specific performance between spouses for nonmaintenance issues. Should non-performance of matrimonial obligations lead to the irretrievable breakdown of marriage, the appropriate remedy would be divorce. No damages are payable for non-performance of matrimonial obligations.

The fact that marriage constitutes a juristic act sui generis rather than an "ordinary contract" stems, it is submitted, from its typical normative structure. Qua social entity marriage has a typical foundational function (foundation) and leading function (destination). The first mentioned function guarantees the particular unity of the social entity and can therefore also be considered to be a conjoining factor. The leading function, on the other hand, indicates the destination of the entity. The determination of the leading function of a social entity is directed by the question what is the primary destination of the entity. ${ }^{35}$

The institution of marriage has a biological foundational function. It is based on the sexual differences between men and women, and the intimate unity of the relationship is guaranteed by the sexual aspect that provides the basis for sexual intercourse between spouses. The marital relationship finds its destination in the ethical aspect that is expressed in love between husband and wife. $^{36}$

The exposition of the marriage relation relationship as set out above corresponds with descriptions depicting marriage as a consortium omnis vitae. In $T \vee T^{37}$ it was held that consortium comprises three elements, namely eros, philia and agapé. In Grobbelaar $v$

34 Van der Vyver and Joubert Persone- en Familiereg 447.

35 Van der Vyver and Joubert Persone- en Familiereg 444.

36 Ibid. See also Joshua $v$ Joshua 19611 SA 455 (GW).

$37 \quad T \vee T 19683$ SA 554 (R). 
Havenga $^{38}$ the court conveys that the concept of consortium is an abstraction comprising the totality of a number of rights, duties and advantages accruing to spouses of a marriage. It proceeds to explain with reference to Best $v$ Samuel Fox ${ }^{39}$ that the consortium can be explained as follows:

Companionship, love, affection, comfort, mutual services, sexual intercourse - all belong to the married state. Taken together, they make up the consortium; but I cannot think that the loss of one element, however, grievous it may be, ... can be regarded as the loss of the consortium ... Still less could any impairment of one of the elements be so regarded. Consortium, I think, is one and indivisible.

It is clear that the explanation of the concept of consortium in both $T \vee T$ and Grobbelaar $v$ Havenga relates closely to the exposition of marriage as a social entity. The eros corresponds with the foundational function of marriage in that there are sexual differences between male and female, which make possible sexual intercourse and guarantee the unity of marriage qua social entity. On the other hand, philia and agapé relate to the concept of companionship, love, affection, comfort and mutual services as explained in Best $v$ Samuel Fox. These concepts, it is suggested, are indicative of the leading function of marriage as set out above.

From the exposition given above, it is clear that sexual differences between male and female play the all-important role of guaranteeing the unity of the marriage relationship. It is this very fact that causes marriage to be regarded as a juristic act sui generis which must be understood as a consortium omnis vitae. Same-sex unions, it is suggested, lack this foundational function and such relationships can therefore not be equated to marriage relationships. The lack of the institutional guarantee provided for by the differences in sex cause such relationships to be purely contractual in nature. ${ }^{40}$

\section{The road ahead}

There are various models of regulation of same-sex relationships. In the German context, for instance, a particular question that needs to be taken into consideration is the fact that the Grundgesetz protects marriage constitutionally. Recognition of same-sex marriage might mean an infringement of constitutional prescripts. ${ }^{41}$ From a South African point of view, however,

38 Grobbelaar v Havenga 19643 SA 522 (W).

39 Best v Samuel Fox (1952) All ER 394.

40 Robinson 1991 THRHR 508.

41 S6(1) of the Grundgesetz provides that "Ehe und Familie stehen unter dem besonderen Schutze der staatlichen Ordnung". In a decision of the Constitutional Court on 17 July 2002 it was held that: "Zum 
there is no such institutional protection of marriage. In fact, in Ex parte Chairperson of the Constitutional Assembly: In re Certification of the Constitution of the Republic of South Africa 1996 (First Certification Judgment) ${ }^{42}$ the Constitutional Court found that a trinity of values (human dignity, freedom and equality) would play an important role in the protection of marriage and family life. These values would prohibit arbitrary state interference in the right to marry or to establish and raise a family. ${ }^{43}$ It is not only the value of dignity for the protection of family life that is emphasized by the Constitutional Court, but also the right to dignity. Dignity, whether conceived of as a right or a value, therefore, is vitally important for the constitutional protection of the family. Against this background, various models of regulation of same-sex relationships will be investigated.

\subsection{The cautious approach}

The most cautious approach in the recognition of same-sex unions would be the establishment of some specific rules relating to the common home, social security, liability for debts incurred by their partners, and inheritance rights for cohabiting partners. ${ }^{44}$ Following this approach, the law would mitigate the hardships that stem from the fact that a long-term partner of a person is legally considered to be on the same footing as a stranger. This piecemeal approach would also be in line with social and economic realities and would constitute a first step away from the old dichotomy "marriage/non-marriage" with its inherent all or nothing point of departure. ${ }^{45}$ However, it is unsatisfactory in that it can be described as regulatory patchwork because of its inconsistency and incompleteness and lack of a coherent and encompassing set of rules for (same-sex) partners.

\subsection{The middle road: a legal relationship defining rights and obligations}

A second approach would be to consider legislation to remedy the legal uncertainty surrounding such relationships. In this instance the emphasis would fall on the stable union in

Gehalt der Ehe, wie er sich ungeachtet des gesellschaftlichen Wandels und der damit einergehenden Änderungen ihrer rechtlichen Gestaltung bewahrt und durch das Grundgesetz seine Prägung bekommen hat, gehört, dass sie die Vereinigung eines Mannes mit einer Frau zu einer auf Dauer angelegten Lebensgemeinschaft ist ..." (italics added) (par 87).

42 Ex parte Chairperson of the Constitutional Assembly: In re Certification of the Constitution of the Republic of South Africa 199619964 SA 744 (CC); 1996 (10) BCLR 1253 (CC).

43 Par [100]. No mention is made by the Court of a positive obligation on the State to protect and further the marriage as an institution.

44 Coester 2002 Eur J Fam L 7 refers to this method as "piecemeal regulation".

45 Coester 2002 Eur J Fam L 8. 
life of the parties. ${ }^{46}$ However, inherent problems prevailing in such an approach relate to the definition of "cohabitants" and the nature of the relationship as well as the "substance" of the legislation. As for the first difficulty, the question that is often raised is whether, for reasons of certainty, the law should require a formal declaration or a certain duration of cohabitation before particular legal rules become applicable. With regard to the nature of the relationship it may be asked whether only sexual or emotional relationships that on appearance resemble a marriage relationship, be accepted. Regarding the substance of the legislation, the appropriate degree of regulation seems to be a problem. A lesser degree offers less protection, while comprehensive legislation has been criticised as "making 'free love' unfree" - as being reactionary rather than progressive. ${ }^{47}$ Perhaps more seriously, such legislation does not create a legal status for the parties - it constitutes only a legal relationship consisting solely of rights and obligations. It therefore, so the argument goes, denies parties involved in such relationships the privileges of the so-called consortium omnis vitae.

\subsection{Creating a legal status: the registered partnership}

A third model of regulation would be that of the so-called registered partnership. The institution of this possibility can be viewed as providing public recognition for the relationship of homosexual partners. In essence partnership legislation creates a legal status analogous to that of marriage. Like marriage, the partnership status is bestowed with several statutory rights, privileges and responsibilities. It also leaves room for contractual arrangements.

Coester indicates that fundamental choices that have to be taken into consideration by legislatures when establishing registered partnerships relate to the gender of the couples and the legislative technique. With regard to the gender of the couple, the choice is whether partnership status should be reserved for same-sex couples, thereby creating a substitute for inaccessible marriage status, or whether it should be open to heterosexual couples as well, thus leaving parties a choice between ordinary marriage and an alternative status similar in substance, but less burdened with traditions and conceptions. ${ }^{48}$ The second choice relates to the legislative technique. In this regard Coester submits that

46 In jurisdictions where such legislation can be found, the law applies more or less equally to hetero- and homosexual partners. See Coester_(n 1) 9.

47 Coester 2002 Eur J Fam L 8-10. The author also refers to Glendon State, Law and Family 91: "The legitimate family prevails after all: In appearance, it has certainly lost ground, but in fact it has imposed the matrimonial model on those who have declined to marry."

48 Coester 2002 Eur J Fam L 11. 
[T] he easiest and most egalitarian way would be to establish the new status, combined with an overall reference to marriage law as to the formation, the effects, and the dissolution of the partnership, perhaps to the exclusion of some specific questions like child related matters (filiation, parental authority, adoption). ${ }^{49}$

However, the alternative would be to formulate a separate set of rules which would allow for the taking into account of the specific nature of same-sex relationships and also to mark a difference between marriage and partnership. In some jurisdictions this method has been used to downgrade the new institution, leaving most aspects of the relationships to be autonomously regulated by the partners. ${ }^{50}$ Another approach would be to paraphrase marriage law with modifications and omissions. Coester explains that this technique is fraught with danger -

... the more marriage-like the provisions on partnerships are drafted, the more likely are comparisons with marriage law and the more obvious become the remaining differences. ${ }^{51}$

This would lead to attacks on the ground of unequal treatment. ${ }^{52}$

\subsection{Submission}

It is submitted that in view of the legal uncertainty that currently exists ${ }^{53}$ and the need that exists for legal reform, it has become imperative for the state through the legislature to provide a sensitive and meaningful legislative framework within which the position of same-sex cohabitants can be accommodated. ${ }^{54}$ It is also suggested that mere cohabitants' legislation will

49 Coester 2002 Eur J Fam L 12.

50 In fact, Coester 2002 Eur J Fam L 12 points out that to avoid any confusion with the institution of marriage, the relevant provisions are not inserted in the family law sections of the French Code Civil, but in the section dealing with persons and civil status.

51 Coester 2002 Eur J Fam L 13.

52 Regarding the position in Germany, Coester provides the following example. In relation to the consequences of a break-up of the relationship, German law puts ex-spouses and ex-partners very much on the same footing as far as matters such as the dissolution of the relationship by court decree, the distribution of property, the allocation of the family home and alimony are concerned. However, the splitting of pension rights, which is mandatory upon divorce of spouses, has been omitted. Should the Partnership Act be attacked on this point before the Bundesverfassungsgericht it would be very difficult to justify this difference.

53 See accompanying text to n 4 supra.

54 The state, after all, has a duty to serve the common good and to protect the rights and interests of all its citizens and all the inhabitants of the country. In enforcing its legal norms it should act in such a way that it respects everybody's freedom, equality and human dignity.

A normative approach will set certain requirements that a phenomenon has to meet to qualify as being that specific thing (in casu a marriage). Although one would - within the parameters of a normative approach - be able to describe various relationships claiming to qualify as a marriage, these relationships will be scrutinized and tested against the criteria of the definition of the social phenomenon. A legal definition will be of a normative (and not merely a descriptive) kind because it is 
not suffice, but indeed that legal provision should be made for a registered partnership. A secure status with a complex set of rights and duties must be provided to partners in such relationship.

The legal status is more than the sum of various rights and obligations, it not only reassures the partners in their internal relations and helps them to gain social acceptance, it although (sic) helps the legislature because it furnishes a clear and reliable basis for the application of the law. The status model is not only called for by reasons of equality, but also by policy reasons: Those who wish to transform their relationship into a status belong to a serious and constructive section of the population - they should be integrated into the social and legal order instead of being excluded or be the subject of discrimination. As to the substance of partnership legislation, the principle of equal protection has to be the starting point. ${ }^{55}$

In view of the conclusions reached in paragraph 3 supra, it is considered not only inappropriate, but also a legal impossibility to open the institution of marriage to same-sex couples.

\section{The constitutionality of same-sex partnership legislation}

The propagation of same-sex partnerships instead of marriage obviously raises the question whether the solution would meet constitutional demands. Throughout the South African Constitution there is a constant refrain that the achievement of equality for all South Africans and the advancement of human rights are important values to strive towards. ${ }^{56}$ This question needs to be addressed against the backdrop of Harksen $v$ Lane and Others, ${ }^{57}$ which was

used in contexts where a decision has to be made as to whether, and if so, which legal consequences flow from a union that qualifies as a marriage and which consequences from something that does not qualify as a marriage.

An historical example will make this clear. In South Africa, a country rich in different cultural traditions, the legal definition of a valid marriage is a monogamous union between one man and one woman. Despite this being the juridical definition applied by the courts, the law also had to make provision for marriage-like relationships in accordance with customary law or religiously based systems. Although the monogamous marriage between one man and one woman was for a long time the only valid marriage, the state had to, and did, provide a framework for dealing with such relationships. It had to make clear the legal status of such relationships and the legal consequences (if any) that flow from such customary and religiously-based unions.

55 Coester 2002 Eur J Fam 19.

56 Cf s 1(a) of the Constitution; Satchwell v The Minister of Justice and Constitutional Development Case Nr CCT 45/01 par 17.

57 Harksen v Lane 19981 SA 300 (CC); 1997 (11) BCLR 1489 par [54]. See also Du Toit v Minister of Welfare and Population Development 2001 (12) BCLR 1225 (T) and De Vos 1996 SAJHR 287 et seq. 
decided under the equality clause in the 1993 Constitution, namely section 8. In this case the court set out the stages of enquiry in cases involving the fundamental right to equality.

[i]t may be as well to tabulate the stages of enquiry which become necessary when an attack is made on a provision in reliance on section 8 of the interim constitution.

They are:

(a) Does the provision differentiate between people or categories of people? If so, does the differentiation bear a rational connection to a legitimate government purpose? If it does not then there is a violation of section 8(1). Even if it does bear a rational connection, it might nevertheless amount to discrimination.

(b) Does the differentiation amount to unfair discrimination? This requires a two stage analysis:

(i) Firstly, does the differentiation amount to 'discrimination'? If it is on a specified ground, then discrimination will have been established. If it is not on a specified ground, then whether or not there is discrimination will depend upon whether, objectively, the ground is based on attributes and characteristics which have the potential to impair the fundamental human dignity of persons as human beings or to affect them adversely in a comparably serious manner.

(ii) If the differentiation amounts to 'discrimination', does it amount to 'unfair discrimination'? If it has been found to have been on a specified ground, then unfairness will be presumed. If on an unspecified ground, unfairness will have to be established by the complainant. The test of unfairness focuses primarily on the impact of the discrimination on the complainant and others in his or her situation. If, at the end of this stage of the enquiry, the differentiation is found not to be unfair, then there will be no violation of section $8(2)$.

(iii) If the discrimination is found to be unfair then a determination will have to be made as to whether the provision can be justified under the limitations clause ... 
It can hardly be denied that legal prescripts preventing homosexuals from marriage differentiate between hetero- and homosexual people individually and qua categories of people. The real question, however, is whether there is discrimination and, if so, whether such discrimination is unfair. It is submitted that there is neither discrimination, nor is such differentiation unfair. In paragraph 3 supra, the conclusion was reached that it would constitute a conceptual fallacy to term the relationship of homosexual couples marriage. This conclusion followed of necessity after it was argued that marriage and same-sex relationships are not part of the same legal genus - marriage is a juristic act sui generis while same sex unions are based on contract in view of the lacking institutional guarantee of the foundational function. The marriage relationship creates a consortium omnis vitae, the rights and obligations of which generally are not enforceable by an order of court. The rights and obligations flowing from same sex unions, on the other hand, are personal rights and obligations based on contract and enforceable by order of court. It is therefore submitted that the provision of registered partnerships for same-sex couples will meet the demands of Harksen and will serve to alleviate the legal uncertainty that currently prevails. 


\section{Bibliography}

Braun 2002 Juristenzeitung

Braun J "Ein neues familienrechtliches Institut: Zum Inkrafttreten des

Lebenspartnerschaftsgesetzes" 2002 (1) Juristenzeitung 23

Braun I (Trost 2002 Kirchliche Umschau)

Trost "Interview with Johann Braun: Marriage and the Family at the Crossroads" 2002

(4) Kirchliche Umschau 25

Braun II (Braun 2002 Juristenzeitung)

Braun J "Ein neues familienrechtliches Institut: Zum Inkrafttreten des

Lebenspartnerschaftsgesetzes" 2002 (1) Juristenzeitung 23

Coester 2002 Eur J Fam L

Coester M "Same Sex Relationships: A Comparative Assessment of Legal

Developments Across Europe" 2002 (4) Eur J Fam L 589

Culhane 1999 Cardozo L Rev

Culhane JD "Uprooting the Arguments against Same-sex Marriage" 1999 (20) Cardozo

L Rev 1119

De Vos 1996 SAJHR

De Vos P "On the Legal Construction of Gay and Lesbian Identity and South Africa's

Transitional Constitution" 1996 (12) SAJHR 265

Eckols 1999 Mich J of Gender and L

Eckols LS "The Marriage Mirage: The Personal and Social Identity Implications of Same-Gender Matrimony" 1999 (5) Mich J of Gender and L 353

Glendon State, Law and Family

Glendon MA State, Law and Family: Family Law in transition in the United States and Western Europe (Elsevier Amsterdam 1977) 
Glendon 1976 Virginia Law Review

Glendon MA "State, Law and the Family: The Withering away of Marriage" 1976

Virginia Law Review 663

Hutchinson 1985 New York University Law Review

Hutchinson AC "Part of an essay on power and interpretation (with suggestions on how to make bouillabaisse)" 1985 (60) New York University Law Review 850

MacDougall 2000-2001 Ottawa Law Review

MacDougall B "The Celebration of Same-sex Marriage" 2000-2001 (32) Ottawa Law

Review 235

Pantazis 2002 SALJ

Pantazis A "Home and the World: Lesbian and Gay Places in the Law" 2002 SALJ 305

Robertson 1998 Denver UL

Robertson KC "Penetrating Sex and Marriage: The Progressive Potential of Addressing Bisexuality in Queer Theory" 1998 (75) Denver UL 1375

Robinson 1991 THRHR

Robinson JA "Gedagtes rondom die huweliksconsortium en egskeiding" 1998 (51)

THRHR 508

Sinclair and Heaton Law of Marriage

Sinclair JD and Heaton J The Law of Marriage based on HR Hahlo: The South African

Law of Husband and Wife Volume I (Juta Kenwyn 1996)

Strasser Legally Wed

Strasser MP Legally Wed: same-sex marriage and the constitution (Cornell University

Press London 1997)

Trost 2002 Kirchliche Umschau

Trost "Interview with Johann Braun: Marriage and the Family at the Crossroads" 2002

(4) Kirchliche Umschau 25

Van der Vyver and Joubert Persone- en Familiereg

Van der Vyver JD and Joubert DJ Persone- en Familiereg ( $3^{\text {rd }}$ ed) (Juta Kaapstad 1991) 
Wardle Same-sex Marriage

Wardle LD "Same-sex Marriage and the Limits of Legal Pluralism" in Eekelaar J and Nhlapo T (eds) The Changing Family: international perspectives on the family and family law (Hart Publishing Oxford 1998) 381-396

Witte Religion and Law

Witte J (jnr) From Sacrament to Contract Marriage, Religion and Law in the Christian Tradition (John Knox Westminister 1997)

\section{Register of acts}

Constitution of the Republic of South Africa 1996

Constitution of the Republic of South Africa Act 200 of 1993

Gesetz zur Beendigung der Diskriminierung Gleichgeschlechtlicher Gemeinschaften of 2001

Grundgesetz für die Bundesrepublik Deutschland (GG) 1949

Judges' Remuneration and Conditions of Employment Act 88 of 1989

Recognition of Customary Marriages Act 120 of 1998

\section{Register of cases}

Baxter v Baxter [1948] AC 274 [1947] 2 All ER 886 (HL)

Best v Samuel Fox \& Co (1952) All ER 394

Du Toit v Minister of Welfare and Population Development 2001 (12) BCLR 1225 (T)

Egan v Canada [1995] 2 SCR 513, 124 DLR $\left(4^{\text {th }}\right) 609$

Ex parte Critchfield 19993 SA 132 (WLD)

Ex parte Chairperson of the Constitutional Assembly: In re Certification of the Constitution of the Republic of South Africa 1996 (First Certification Judgment) 19964 SA 744 (CC)

Ex parte Chairperson of the Constitutional Assembly: In re Certification of the Constitution of the Republic of South Africa 19961996 (10) BCLR 1253 (CC)

Grobbelaar v Havenga 19643 SA 522 (W)

Harksen $v$ Lane NO and Others 19981 SA 300 (CC)

Harksen $v$ Lane NO and Others 1997 (11) BCLR 1489

Hyde $v$ Hyde and Woodmansee (1866) LR 1 P\&D 130

J \& Another v Director General: Department of Home Affairs and Others 20035 SA 605

(D\&CLD)

Jones v Hallahan 501 SW 2d 588 (Ky 1973) 
Joshua v Joshua 19611 SA 455 (GW)

Langemaat $v$ Minister of Safety and Security 19982 All SA 259 (T)

Layland v Ontario (Minister of Consumer and Commercial Relations) (1993), 14 OR (3d)

658, 104 DLR $\left(4^{\text {th }}\right) 214$ (Div Ct)

$M v H$ [1999] 2 S.C.R. 3, 171 D.L.R $\left(4^{\text {th }}\right) 577$

National Coalition for Gay and Lesbian Equality v Minister of Home Affairs 19993 SA 173

(C)

National Coalition for Gay and Lesbian Equality v Minister of Home Affairs 20002 SA 1 (CC)

National Coalition for Gay and Lesbian Equality v Minister of Home Affairs 20001 BCLR 39

(CC)

Satchwell v The Minister of Justice and Constitutional Development Case Nr CCT 45/01

Seedat's Executors v The Master (Natal) 1917 AD 302

T v T 19683 SA 554 (R)

$V v V 19984$ SA 169 (C)

Van Niekerk v Van Niekerk 19594 SA 659 (GW)

Van Rooyen $v$ Van Rooyen 19942 SA 325 (WLD)

Venter v Venter 19494 SA 123 (W) 